\title{
De NoRDISKe KRIMINALISTFORENINGER 2008
}

\section{Dansk Kriminalistforening}

Foreningens formand er direktør William Rentzmann og sekretær og kasserer er advokat Bjørn Høberg-Petersen. Bestyrelsen bestod i 2008 endvidere af professor Flemming Balvig, rigsadvokat Jørgen Steen Sørensen, dommer Peter Garde, professor Vagn Greve, politimester Lars Rand Jensen, overlæge Peter Kramp, forskningschef Britta Kyvsgaard, professor Gorm Toftegaard Nielsen, departementschef Michael Lunn, højesteretsdommer Poul Dahl Jensen og fængselsinspektør Lene Møller-Nielsen.

Foreningens æresmedlem er professor, dr. jur. Knud Waaben. Knud Waaben afgik ved døden i november 2008. I forbindelse med årsmødet d. 5. februar udtalte formanden mindeord om Knud Waaben og forsamlingen holdt et minuts stilhed.

Årsmødet i foreningen fandt sted den 5. februar 2008. Efter generalforsamlingen holdt forskerne Jonas Havelund og Kristian Rasmussen og chefkriminalinspektør Per Larsen omlæg om 'Fodboldvold og politiets håndtering heraf'.

Dansk Kriminologisk Selskab, der er et datterselskab til Dansk Kriminalistforening, arrangerede seks møder i 2008. Den 26. januar indledte forskningschef Britta Kyvsgaard mødet med et oplæg om en 'Ny undersøgelse om gaderøverier'. Den 22. april blev der afholdt et møde på Politihistorisk Museum, hvor professor Henrik Stevnsborg og forfatter Frank Bøgh holdt oplæg om 'Politiet under retsopgøret'. Den 9. oktober indledte politidirektør Johan Reimann, formand for Regeringens Ungdomskommission, mødet om kommissionens overvejelser vedrørende 'forceldreansvar'. Den 13. november var foreningen medarrangør ved et gæsteseminar med professor Howard Zehr, der fortalte om 'Essential and critical issues in Restorative Justice'. Den 20. november talte rigspolitichef Torsten Hesselbjerg om 'Prioritering af politiets opgaver - er det politiet eller politikerne der bestemmer'. Årets sidste arrangement blev afholdt den 4. december og var en gentagelse af arrangementet på Politihistorisk Museum, fordi der var så stor interesse for forårets arrangement.

Dansk Selskab for International Strafferet og EU-ret, der også er et datterselskab til Dansk Kriminalistforening holdt tre møder i 2008. Den 15. januar indledte kommitteret i Justitsministeriet Nina Holst Christensen om 'Reformetraktaten'. Den 30. januar afholdt selskabet et møde om 'Terrorlovgivning $i$ et retsstatsligt perspektiv'. Den 8. april holdt politimester, chef for PET, Jakob Scharf oplæg om 'Internationalt samarbejde om terrorbekcempelse'.

Ved årets udgang havde foreningen 336 medlemmer. 


\section{Kriminalistföreningen i Sverige}

Vid årsmötet den 11 juni 2008 valdes generaldirektören Jan Andersson till ny ordförande. Till ny styrelseledamot valdes generaldirektören Gudrun Antemar. Ledamöterna Fredrik Wersäll, Sten Heckscher, Tomas Rothpfeffer, Lena Berke, Agneta Bäcklund, Magnus Ulväng, Carin Götblad, Ove Horned, Peter Lindström och Mattias Larsson omvaldes. Lotta Gustavson omvaldes som revisor. Till ny revisor utsågs departementsrådet Annika Lowén. Till ny revisorssuppleant valdes ämnesrådet Patrik Örnsved.

Styrelsen har under året sammanträtt två gånger.

Vid årsmötet deltog pressombudsmannen Yrsa Stenius och chefsrådmannen Mari Heidenborg i en diskussion om mediernas rapportering om brott. Vilket ansvar har media? Hur är det att vara domare i ett medieuppmärksammat mål? På höstpuben var ämnet: Vad ska det kosta att ta ett liv. Straffet för mord diskuterades under ledning av advokat Johan Eriksson och docenten Hans-Gunnar Axberg. Vid höstmötet avhandlades vilken betydelse återfall ska ha för straffmätningen i brottmål. Diskussionen tog avstamp i Straffnivåutredningens slutbetänkande Straff i proportion till brottets allvar och leddes av riksåklagaren Anders Perklev och professorerna Petter Asp och Andrew von Hirsch.

Föreningen hade den 31 december 2008 ca 300 medlemmar.

\section{Kriminalistforeningen i Island}

Formanden for den Islandske Kriminalistforening er Thorsteinn A. Jónsson, generalsekretær i Højesteret.

Ved årets udgang var der 11 medlemmer i foreningen.

\section{Kriminalistföreningen i Finland - Suomen Kriminalistiyhdistys}

Föreningens styrelse har under redogörelseåret haft följande sammansättning; ordförande: professor Kimmo Nuotio, viceordförande: generaldirektör Esa Vesterbacka, sekreterare: jur.dr. Sakari Melander, kassaförvaltare: jur.kand. Mikko Virkamäki. Styrelsens övriga medlemmar bestod av följande personer: överläkare Aulikki Ahlgren, vicechef Sanna Heikinheimo, statsåklagare Päivi Hirvelä, professor Pekka Koskinen, överdirektör Maija Kukkonen, överlärare Matti Laine, institutionschef Tapio Lappi-Seppälä, justitieråd Liisa Mansikkamäki, hovrättsråd Tuomas Nurmi, advokat Jouko Pelkonen, ledande häradsåklagare Antti Pihlajamäki, konsultativ tjänsteman Tapio Sarvanti, generalsekreterare Hannu Takala och lagstiftningsdirektör Asko Välimaa. Styrelsen sammanträdde två gånger år 2008; den 6 mars och den 11 november. Även juris studerande, sedermera jur.kand. Emilia Kaikkonen har varit studentmedlem i styrelsen.

Professor Inkeri Anttila är hedersmedlem i föreningen. 
Föreningens årsmöte hölls den 14 april 2008 i utrymmen av Brottspåföljdssektorns utbildningscentral. Temat vid årsmötet var "Erfarenheten av den nya fängelselagen". Generaldirektör Esa Vesterbacka och chefen Anna Arola höll inledningar till temat.

Föreningens höstmöte hölls den 19 november 2008 i utrymmen av Helsingfors hovrätt. Temat var "Hovrättena och brottspåföljdspraxisen". Det handlade särskilt om rollen av olika informella rekommendationerna i syfte att öka enhetligheten av straffmätningspraxisen. Inlägg hölls av överdirektör Tapio Lappi-Seppälä, professor Veli-Pekka Viljanen och tingsdomaren Kari Lappi.

Föreningens Internetsidor har uppdaterats på adressen $w w w . k r i m i n a l i s t i y h-$ distys.fi.

Vid årets slut hade föreningen 254 medlemmar.

\section{Norsk Kriminalistforening}

Leder er lagdommer Anne-Mette Dyrnes. Styret har i 2008 ellers bestått av følgende personer: juridisk rådgiver ved Spesialenheten for politisaker Guro Kleppe (nestleder), professor Asbjørn Strandbakken, professor Paul Larsson, direktør i Domstolsadministrasjonen Tor Langbach, Advokatfullmektig Eldbjørg Håkonsen Martinsen (varamedlem) og daglig leder i borgerrettsstiftelsen Stopp diskrimineringen Berit Vegheim (varamedlem). Foreningens sekretærer er førstekonsulent Knut-Fredrik Hustad og advokatfullmektig Gemetchu Hika.

Foreningen har i løpet året arrangert tre debattmøter. Etter årsmøtet 13. februar 2008 var det debatt om temaet: "Fritz Moen-rapporten (NOU 2007: 7) - hva kan vi lære og hvilke endringer bør foretas i strafferettspleien?". Innledere var statssekretær i Justisdepartementet Astrid Aas-Hansen, professor Henry John Mæland og statsadvokat ved riksadvokatembetet Johan Kr. Øydegard.

Den 5. juni 2008 arrangerte foreningen møte om temaet: Datalagringsdirektivet (EU-direktiv 2006/24 om lagring av trafikkdata). Innledere var professor Thomas Mathiesen, stipendiat Inger-Marie Sunde og seniorrådgiver ved Datatilsynet Guro Slettemark.

Den 10. november 2008 arrangerte foreningen debatt om tema: "Kriminalomsorgsmeldingen - en renessanse for troen på straffens individualpreventive virkning". Innledere var justisminister Knut Storberget, Yngve Hammerlin, forsker ved fra Kriminalomsorgens utdanningssenter (KRUS) og advokat Frode Sulland, leder av Forsvarergruppen av 1977.

Det ble holdt to styremøter i 2008.

Ved årsskiftet 2008/2009 var det registrert ca. 200 medlemmer. 